\title{
Parody of a Life Which Is Elsewhere
}

\author{
Javad Momeni \\ MA in English Language and Literature \\ Faculty of Foreign Languages and Literatures \\ University of Tehran,Tehran, Iran \\ E-mail address: j.momeni364@yahoo.com
}

Keywords: parody, identification, fantasy, being, symbolic, imaginary, Lacan, Bakhtin

\begin{abstract}
Life Is Elsewhere is a reflective introspection into the life of a young poet and of his demanding mother. Kindera depicts the mother as a woman feeling unworthy of love who relishes the fantasy of being Jaromil's ethereal mother in order to escape from her actual bodily deprivation and resolve her psychological tensions. On the other hand, Jaromil's portrait as a young poet involves his consonant, in Lacan's terms, imaginary and symbolic identifications which lead him to an unending alienation in the context of a socialist system. Reading the novel in the light of Bakhtin's ideas on parody and its polyphonic nature illuminates Kundera's parodic treatment of motherhood, poetic, political and historical discourses, and especially his use of parody as a political means to oppose the domineering voice of totalitarianism. However, by giving parody an ontological status, Kundera considers it as the inevitable destiny of a human being who has forgotten his authentic "being" and ignored all his existential possibilities opened up to realization. Applying this notion to Kundera's relation to his characters, Jaromil and the middle-aged man, implies that these two characters are, in fact, the parody of the two stages of Kundera's own life and that of his generation's.
\end{abstract}

\section{INTRODUCTION}

Life Is Elsewhere is a reflective introspection into the life of a young poet who takes his incognizant steps toward the death and of his mother who gets so absorbed in her fantasies that she falls in a narcissistic love with his son. The novel begins with the mother's conceiving by a young engineer who pushes her for an abortion. The mother (Maman), however, declines his request and asks her well-off parents to intervene and persuade the engineer to marry her. Maman, resentful of the husband, fancies conceiving her son by Apollo, and names him as Jaromil, a name which in Czech bears almost the same implications as those of Apollo's. Due to the mother's family's affluence and her unremitting affection, Jaromil is raised a spoiled child whose early attempts at rhyme are welcomed, mainly by his mother, as signs of a would-be ingenious poet. At school, although usually aloof, he cements a boyhood friendship with the janitor's son, which foreshadows his presence later in Jaromil's life.

As Jaromil grows up, the emotional bond between his parents loosens more and more and his father's influence diminishes in the family. When Jaromil is nearly 13 years old, he becomes a student of the artist who nourishes his mind with the surrealistic notions of art and poetry. Jaromil produces the drawings of humans with dogs' faces which the painter admires passionately; nonetheless he later directs his attention to poetry. At this time, Maman starts a secret affair with the artist but feeling disgraced by his outrageous manners she decides to end it. Jaromil, reaching his puberty, desperately endeavors to win the heart of girls and sleep with them; however, when the red-headed girl, his second girlfriend, has him have sex with her, he feels terribly distressed by such a glaring erotic experience. Meanwhile, the Communists seize the power in Czechoslovakia in a coup and Jaromil determines to renounce the surrealist style and devote his rhyme and rhythm to the ideals of the new revolution.

Meeting the janitor's son again exerts undue influence on Jaromil's life. His authority as a police official who is legally allowed to investigate the private lives of people, and even torment them, leads Jaromil to consider him as a real man. After a police poetry night, Jaromil and his old friend 
are invited to an attractive female director's flat, where Jaromil refuses to make love to her only because he is embarrassed about his ludicrous underwear. Later in the novel, Jaromil, in an agitated state, reprimands his red-headed girlfriend for being late on their date. She justifies her delay on the grounds that her conversation with her brother who intends to secretly go abroad lasted too long. Jaromil feels it his duty to notify the police (the janitor's son) of this stealthy departure, and, consequently, both the red-headed girl and her brother are apprehended. Then , in the narrative, there is a significant shift informing us of the girl's meeting with her former middle-aged lover, which sheds light on Jaromil's death and illuminates the story of the girl's delay on her date with Jaromil, when she was, in fact, late from having a rendezvous with her middle-aged lover.

\section{FANTASY AND THE MOTHER}

M. H. Abrams, in his Glossary, considers parody as a variety of high burlesque which "imitates the serious manner and characteristic features of a particular literary work, or the distinctive style of a particular author, or the typical stylistic and other features of a serious literary genre, and deflates the original by applying the imitation to a lowly or comically inappropriate subject." (Abrams,38) Bearing in mind that hagiography is a book about somebody's life that makes it appear more awesome than it really is or was, it can be said Life Is Elsewhere is a parody of the hagiography of a young poet. In fact, Kundera has extracted the core of the lives of Rimbaud, Shelley, Lermontov, and others to create a typical lyric poet, Jaromil. But, what is this covert core to be revealed? it is nothing but the presence of a demanding mother, a specific sort of woman, who, isolated within the corporal deprivation and divested of a unconditional love realized in the men she meets, tries to actualize all her dissatisfied desires in her own son (Nelson ); the poor boy who, relishing the fantastic unity with the mother as an unending source of fulfillment, take his wobbly and unstable steps into maturity, the world of neurotic frustration.

Married to an unwilling man, Jaromil's mother fancies considering him as her own creation, seeing herself as an ethereal mother and modeling herself on the Virgin Mary (giving birth to a child with no physical intervention of a man), and prefers to take Apollo (known as a god of light and the sun, truth and foretelling, healing, plague, music, poetry, and more) as her model for Jaromil,

"Instinctively modeling herself on the Virgin Mary, who became a mother without the intervention of a human begetter and thus the ideal of maternal love without a father's troublemaking interference, she felt a provocative desire to name her child Apollo, a name that to her meant "he who has no human father." But she knew that her son would have a hard time with such a pretentious name and that it would make both him and her laughingstock. So she looked for a Czech name that would be worthy of a young Greek god and came up with Jaromil (which means "he who loves spring" or "he who is beloved by spring"), and this choice was approved by everyone." (Kundera,2000,7)

Enjoying such fantasies, the mother seeks to escape from her actual bodily privation. These fantasies, psychoanalytically speaking, work as a scene onto which her unconscious desires are projected. In Lacanian terminology, fantasy functions as "an imagined scene in which the subject is a protagonist, and always represents the fulfilment of a wish (in the last analysis, an unconscious wish) in a manner that is distorted to a greater or lesser extent by defensive processes." (Homer 85) indeed, by identifying herself with these mental images and fancies she delights in narcissistically, the process which Lacan calls imaginary identification ,the mother realizes her ego in the imaginary order and constitutes her imaginary identity (ideal ego) or what Lacan names as i(o). (Zizek 95-144) However, her ideal ego stands in a sharp contrast to her actual, physical divestiture, particularly in regard to her relationship with her man; this conflict is exactly where a vexing question hunts her mind, "How does she look like in her husband's eye?"

"Was she then happy at last? Not quite: she was torn between doubt and confidence; when she undressed before the mirror she looked at herself with his eyes and sometimes found herself arousing, sometimes vapid. She handed her body over to the mercy of another's eyes - and that caused her great uncertainty." (Kundera,2000,9) 
Encountering the enigma of his desire, in point of fact, she is (unconsciously) led to put forward this fundamental question "Where am I in his desire?, a particular form of the (universal) Lacanian conundrum "What am I in the Other's desire?" Or "Che Vuoi?" which, metaphorically, makes a hole or "gap" in her actual existence and causes a "lack" in her being as a desiring subject. As Homer points out, our fantasy is an answer to this crucial question and it is actually through this fantasy we, as human beings, get to know how to desire and we are formed as a desiring subject (Homer 86-7); the point that sheds light on the puzzle of the mother's fantasies which are, unconsciously, meant to fill the hole ( and gap) in her reality and which represent the (desired) fulfillment of her deepest unconscious wishes.

The fact that these fantasies act as her last shelter to which she seeks refuge in order to overcome her desperation is the embodiment of the Lacanian thesis that "the last support of what we call reality is a fantasy".(Zizek,47); the support that provides the (apparent) integration and uniformity for what we conceive as reality. Therefore, It seems to us that if the mother refuses to indulge such fantasies, her reality will collapse in the face of frustration and disappointment. In addition, standing on the verge of the question "Che Vuoi?", the mother gets involved in symbolic identification, " the identification of the subject with some signifying feature, trait (I), in the big Other, in the symbolic order.'(Zizek,116) These signifying traits are nothing but "the engineer's qualities", "... [S] he wanted to identify herself with the engineer's qualities, because in contact with them her sadly modest body ceased to doubt and, to its own astonishment, began to enjoy itself." (Kundera,2000,9)

By identifying with these traits, the process which Lacan calls symbolic identification, the mother realizes her "self" in the symbolic order and constitutes her symbolic identity (ego-ideal) or what Lacan names as I(o).( Zizek 95-144). Blissful, although, she seems to be at first sight, the distinction between symbolic and imaginary identification helps to uncover the basic psychological tension she feels: "...II] maginary identification is identification with the image in which we appear likeable to ourselves, with the image representing 'what we would like to be', and symbolic identification, identification with the very place from where we are being observed, from where we look at ourselves so that we appear to ourselves likeable, worthy of love." (Zizek,116)

The mother finds herself a miserable woman unworthy of love, inasmuch as she looks at and observes herself from where her man stands. Indeed, through this symbolic identification, her egoideal is nothing but an "arousing, sometimes vapid" body playing the role of a wife in a contracted marriage approved by the laws of the symbolic order. This helplessness, and her consequent mental obsession with her body, pushes her more forcibly to identify with the image of being Jaromil's ethereal mother and to shape her ideal ego through imaginary identification. It can be said the conflict she feels between her ego-ideal and ideal ego leads her to resolve her psychological tension in Jaromil's (seemingly) integrated personality.

\section{DILEMMA AND ALIENATION}

On the other side, Jaromil's childish rhymes and rhythms, thorough the fate his mother's imposed on him, grows to the young poet she wishes. In a stark contrast to his helplessly romantic mother, Jaromil himself is not sentimental; as his fiction on the imaginary character, Xavier, shows, he is a really promising poet and writer. Jaromil's fictional hero Xavier flies into his sweetheart's window to fulfill his oedipal wishes, "The window was open, and he was convinced that this was an invitation, a silent, private sign meant only for him. He couldn't resist. He climbed up on the parapet. The window was separated from the bridge by a deep gap that ended in cobblestones. The schoolbag would hamper him. He hurled it through the open window into the murky room and jumped. By extending his arms Xavier could touch both sides of the high rectangular window frame he had jumped into, and he entirely filled its height..." (Kundera,2000,83) 
However, facing the real world and actualized in Jaromil, this fictional and lyrical character finds no opportunity to achieve his oedipal wish-fulfillment. The domineering presence of the "Name-of-the Father" which is epitomized by society and its norms and rules (Stavrakakis, 33) eliminates the possibility of gratifying such desire and offers Jaromil no choice but to become something of a rebel against it and perpetrate the symbolic patricide to overthrow the dominant figure of "Father". In fact, Kundera draws a universal picture out of Jaromil's predicament through posing his appalling dilemma in the heart of the never-ending, problematic symbiosis of "lyricism" and "revolution": "...Vitezslav Nezval cried out to his reader, and Baudelaire wrote: "One must always be drunk ... on wine, on poetry, or on virtue, as you wish. ..." Lyricism is intoxication, and man drinks in order to merge more easily with the world. Revolution has no desire to be examined or analyzed, it only desires that the people merge with it; in this sense it is lyrical and in need of lyricism." (Kundera,2000,260-1)

Kundera's portraying Jaromil as an artist carries some ironic implications. Actually, Jaromil'a driving ambition to become a great artist is nurtured by the avant-garde painter in whose classes Jaromil takes part. While addressing the mother, the painter commends the "non-identity of concept and object" in Jaromil's drawings of faceless and headless human beings and claims that his drawings provide the most realistic representation of the aftermath of the war: "Don't you feel there's some kind of link between your son's vision and the war that shakes us every hour of our lives? Hasn't the war deprived man of his face and head? Aren't we living in a world where headless men only desire decapitated women? Isn't a realistic vision of the world the emptiest of illusions? Aren't your son's childish drawings much more truthful?" (ibid,47) The emphasis on the non-identity of the visual signs and their references reminds us of Adorno's belief in dialectics as "the consistent sense of non- identity" between thought and thing (Wilson, 75) whose revolutionary potentiality he considers to disprove the assumptions of identity philosophy (positivism) which only confirms the status quo "by simple adherence to given facts" (ibid).

However, when we remember that Jaromil fails to draws a human face out of his inability, the painter's pompous remarks on his talent seem ironically absurd.( Kundera,2000,131-2) Furthermore, when we trace back Jaromil's inclination to "merge with" revolution just to one of his childhood reactions to his "demanding mother", the ironic aspects of his portrayal in which he miserably attempts to escape from his suffocating, symbiotic relationships with the mother and of his naïve entrance into the world of political causes get more and more illuminated: "...[S]he took hold of his head and began to comb him ... all he could do was wear his cruel grin [...]Mama stepped back to appraise her work with the comb, then, turning to her guests: "Good God, can you tell me why this child is making such a nasty face? And Jaromil swore that he would always be on the side of those who want radically to change the world." (ibid,151)

$* * *$

Both Jaromil's imaginary and symbolic identification have their own alienating dimension.Desperately wanting to be a real man, he jumps out of his insulated life just into identifying himself with the images or signifying traits. As Seaton Points out, "Jaromil's passion for being a revolutionary artist is partly the result of the notions he has got from "the avant-garde poets and painters of the interwar generation." (Seaton) At the level of imaginary identification, the image of a great revolutionary poet he identifies with is in a sharp contrast with his actual life in which he isn't even entitled, by the mother, to choose his underwear. This image which is a far cry from his real life turns out to be a self-estranging one and, therefore, forms his alienated ego in the imaginary order. In addition, as we scrutinize his symbolic identification, we see Jaromil always identifying with signifying traits of those around him: with his ugly red-headed girlfriend he begins to feel like losing beauty (idealistically, to level down his inflated self to that of the humble mass), with the gorgeous film-maker woman who is supposed to film his life he enjoys feelings of good looks and with the policeman who was his boyhood friend, he flirts with the idea of manhood: 
"They shook hands and exchanged smiles. With this smile in his soul (the splendid wrinkled smile of a man), Jaromil left the Police Building. Descending the broad front steps, he looked at the frosty morning sun rising over the city rooftops. He breathed the cold air, felt exuberant with the virility that flowed from his every pore, and felt like singing. At first he thought he would go straight home, sit down at his desk, and write poems. But after a few paces he turned around; he didn't want to be alone. It seemed to him that during the past hour his features had hardened, his step become firmer, his voice grown lower, and he wanted to be seen in this transformation”.(Kundera,2000, 350-1)

Joromi's identification with these signifying traits, the floating signifiers, ends in a further alienation in the language (and symbolic order) due to the fact that these signifiers have no signifieds and that their signifieds themselves are just "the effect of transferential illusion, an imaginary entity".(Stavrakakis,27) Indeed, in Lacanian framework, "any identity resulting from identification is always an unstable identity ... since every identification is marked by an alienating dimension".(ibid,34) Therefore, Jarimil's constant identifications with the images and signifiers bring him nothing except a non-identity and eternal self-alienation .The issue of alienation in the context of a socialist system, however, causes us to face an important question.

Karl Marx , in his work "Economic and Philosophic Manuscripts of 1844", has identified alienation as a direct result of the relations of production in the capitalist system. According to him, under capitalism, economic alienation emerges from the everyday activities of an individual (and not just from his mental perceptions). In Marx's opinion, the alienation in the context of labor has four aspects: 1. alienation of the worker from the work - from the outcome of his work, 2. alienation of the worker from working - from the act of producing, 3. alienation of the worker from himself as a producer, and 4. alienation of the worker from other workers (Marx, 71-168). Although the idea of alienation has not been explicitly mentioned in Marx's later writings, but it has been influential on his other works, especially on "Das Kapital" and the idea of "commodity fetishism" which has a central role in his economic analyses. In the end, Marx's ultimate solution for the human emancipation is the abolition of private property and the establishment of common ownership (socialism).Nevertheless, the problem that Kundera's novel presents in conflict with the theory of Marx is a challenging and serious issue. How does Jaromil, who shares the same living-world with Kundera, undergo the experience of alienation in a socialist system? This serious question which, in Macherey's terms (Macherey15-50), lies in the unconscious of Kundera's text raises a more fundamental question: Is socialism a practical way to liberate the humans from the alienation? Or is the alienation a pervasive and indelible part of human involvement in the world, beyond any experience limited to a certain class, race or gender?

\section{PARODY: A NEW VISION}

Bakhtin's prime reflections on the definition of parody focuses on parody's being a field for the clash of voices ,parody's polyphonic nature, its being double-voiced, and its carnivalesque role. He believes that parody responds to its original subject mainly through a kind of laughter. (Bakhtin, 41-73) The laughing attitude of parody, then, establishes a battlefield wherein the original subject is contested. In order to involve the original subject into a dialogue, parody must necessarily represent it, that is, there must be at least two voices present in a parodic work. One of them is the voice of parody and the other is that of the original subject, “... [I] n parody two languages are crossed with each other, as well as two styles, two linguistic points of view, and in the final analysis two speaking subjects. It is true that only one of these languages (the one that is parodied) is present in its own right; the other is present invisibly, as an actualizing background for creating and perceiving." (ibid,52) The existence of a second voice -or more- in a literary work broadens the perceptual and conceptual horizon of the text through the polyphony and, more importantly, destabilizes the authority of the first domineering voice. In fact, the polyphonic nature of parody which actualizes itself in the clash of voices contributes to its carnivalesque feature with which parody undermines the hierarchy of voices and exposes the authorial or sacred voice to ridicule. 
Furthermore, Bakhtin holds that a variety of issues can be considered as the original subject of parody: a person's style of speech, his typical manner of perceiving the world, the verbal and formal characteristics of an author's works or of a specific genre and, particularly, the axiomatic premises and doctrines informing discourses or ideologies (ibid).

Reading Kundera's Life Is Elsewhere in the light of Bakhtin's ideas on parody can be illuminating and enlightening. Generally, the novel seems to be a parody of motherhood and poetic discourses. As we observed, the motherhood discourse which always connotes unconditional love, sacrifice, protection and emotional safety, in this novel, informs the character of a (typical) "demanding mother" who miserably seeks to resolve her psychological tensions in her son's existence; a demanding mother who is so obsessed with, and so possessive of, her son's heart matters that she finds herself being on a fight with his potential lovers, "Mama waits for her son ... she tells herself that ... she will go on fighting. Yes, that is exactly how she feels: she will fight, she will not permit anyone to take him away, she will not allow herself to be separated from him, she will be with him always, she will follow him always." (Kundera,2000, 398); nonetheless, at Jaromil's deathbed, she manages to own his whole existence and relishes the thought of her ethereal unity with her moribund son and "feels a sense of boundless power ... she is linked to her son more strongly than ever; she and he form a single soul, a single mind; she and he form a single universe carved from the same matter." (ibid, 413) In fact, Kundera's parody of motherhood discourse seems to be intended to shatter the false illusions formed around the picture of a too compassionate mother who puts tremendous emotional burden on her child and entangles him in an abysmal, suffocating symbiosis.

On the other side, the portrait of Jaromil as a young poet drops some parodic hints at the poetic discourse. Jaromil's life paralleling that of the other great poets mentioned in the novel, as Kundera depicts it, encourages us to venture a guess about one of their universal, existential characteristics: their strenuous efforts to release themselves from the fixation in the (pre)oedipal stage(s) of their psychic development; as if all the poetic discourse depicted here by Kundera has been produced in a fashion of the ill-fated attempts to oppose the figure of the Father which only harbor the romantic illusions of changing the world. Jaromil's poems and those by the poets of his ilk which summon up the images of natural entities and seem to convey the impressions of spiritual unity with nature as the unending source of fulfillment are, indeed, the projection of their frustrated wish to regain the fantastic unity with the mother, however, in their actual life, such a desire ends in their inevitable early death in their youth, an early return to the Earth's motherly womb, the grave!

The way Kundera deliberates on his own political and historical situation has, also, some significant implications in regard to the laughing attitude of parody which Bakhtin emphasizes. The parodic nature of Kundera's novel, through its polyphony, provides no room for a dominant voice to treat the history and politics seriously. As Ricard mentions, Kundera securitizes both of them " with a distance that has nothing to do with scientific or historical "objectivity", nor with the analysis of an opposition militant ...It is an absolute, unconditional distance, that of unbelief ...."(Ricard) Belief in a predetermined stage of history, as it lies at the core of the vulgar Marxist doctrines, deprives history of its unpredictable being and places the burden of the dead history on the shoulders of the human subjects who are inevitably doomed to their historical duty of carrying such a corpse. Kundera never succumbs to a belief in predestined history and adopts a stance of "unbelief" towards any serious treatment or ideological justification of historical events. The parodic accents of Kundera provide "a radical demystification, an immense burst of laughter, such as only literature can aim at politics or history in order to strip them pitilessly naked, to reduce them to nothing, which is not at all an attempt to escape them, but rather to penetrate them, to profoundly defuse them, and to denounce their horrors, all the more scandalous for no longer having any justification beyond the aberrant discourse in which they clothe themselves".(ibid) To put it more clearly, Kundera's parody of the political and historical discourses, at first, generates literary representations of the deepest principles behind them, and then, especially through its laughing attitude to their determinism, this parody works as a political means in his hands to threaten, or 
subvert, the domineering voice of the totalitarian system which imposes itself on his living world. As we mentioned earlier, in order to involve the original subject into a dialogue, parody must necessarily represent it, that is, there must be at least two voices present in a parodic work; one of them is the voice of parody and the other is that of the original subject. Kunder chooses the present motherhood, poetic, political and historical discourses as his original subjects and, through his first voice, makes them the object of his artistic representations; then, through his second voice, that of parody, lays their hidden premises bare and invites us to laugh at their nudity. $* * *$

Bakhtin's thoughts on parody are mainly focused on its stylistic and linguistic dimensions, but an ontological view on parody prevails in the lines of Kundera's novel. Toward the end of the novel, significantly, the narrator diverges from the main route of the story and jumps into the apartment of a "middle-aged man", a philanderer who has had affairs with Jaromil's girlfriend and knows about his death. Through the presence of his guest, Jaromil's girlfriend, we are provided with the insight into the interwoven net of happenings hastened by Jaromil himself, the irrational events that he was ignorantly unaware of. In his Art of the Novel, Kundera introduces this middle-aged man as his most intimate and closest character to himself; (Kundera, 1986, 63) the fact that prompts more reflections on the relationship between the man, Kundera and Jaromil. Kundera, as he does in his other novels like the Book of Forgetting and Laughter, The Farewell Party and Slowness, exhibits his consummate skills at presenting an ironic picture of his characters, but is this (dramatic) irony the only device Kundera uses to enact his characterizations?

Kundera's ironic representation of his characters which is accompanied by much sympathy from his side provokes a discussion on the existential possibilities realized and explored by the author himself.

Restating Hermann Broch's idea on the task of the novel, Kundera holds that the raison d'être (reason of being) of the novel is to delve into and raise the undiscovered existential possibilities, "the sole raison d'etre of a novel is to discover what only the novel can discover. A novel that does not discover a hitherto unknown segment of existence is immoral. Knowledge is the novel's only morality." (ibid, 7-10) This knowledge which prescribes the standards of the novel's morality rises out of the novelist's reflections on the existence of human being whose life is (in Heidegger's terms) nothing but "being-in-the-world". Kundera believes that novel has to "scrutinize man's concrete life and protect it against "forgetting of the being" (ibid), therefore, all what a novel can say must be grounded in the perspective of a human being whose "being-in-the-world" is in danger of forgetting. In addition, Kundera asserts his claim about an authentic, existential relationship between the author and his characters. He considers his own creations as his own unrealized existential possibilities, "the characters in my novels are my own unrealized possibilities. That is why I am equally fond of them all and equally horrified by them. Each one has crossed a border that I myself have circumvented. It is that crossed border (the border beyond which my own I ends) which attracts me most. For beyond that border begins the secret the novel asks about. The novel is not the author's confession; it is an investigation of human life in the trap the world has become." (Kundera, 1984, 83)

When Kundera's ideas about the task of the novel and his characters are considered alongside his attitude towards the (ludicrous) repetition of the same existential situations of the world, a new vision of parody is conjured up, "A shot rings out, Lermontov clutches his chest, and Jaromil falls to the icy concrete floor of the balcony. O my Bohemia, how easily you transform the glory of a pistol shot into the buffoonery of a kick in the pants! And yet, should we laugh at Jaromil because he is merely a parody of Lermontov? Should we laugh at the painter because he imitated Andre Breton with his leather coat and his German shepherd? Was Andre Breton not himself an imitation of something noble he wished to resemble? Is not parody the eternal destiny of man? Besides, nothing is easier than to reverse the situation: A shot rings out, Jaromil clutches his chest, and Lermontov falls to the icy concrete floor of the balcony." (Kundera, 2000, 404) Kundera seems to believe that if Lermontov, Breton, Shelley, and Rimbaud were in Jaromil's place, they would spring 
into the same actions and would ridiculously duplicate Jaromil's life in parody. Giving parody an ontological status, Kundera sees it as the unavoidable fate of a human being who has forgotten his authentic "being" and ignored all his existential possibilities opened up to realization. Particularly, applying these notions to Kundera's relation to Jaromil and the middle-aged man leads us to conclude that Jaromil and the middle-aged man are the parody of two different phases of Kundera's own life and that of his own generation's; one (Jaromil) signifies the revolutionary enthusiasm and the unbridled passions ,specifically, for communist revolution of Czechoslovakia in 1948 (in which Kundera himself participated) and the other ,the middle-aged man whose presence sheds light on Jaromil's demise and sounds the death knell for all those passions, indicates the post-revolutionary frustration and disillusion.

\section{CONCLUSION}

In this paper we have focused on the way Kindera depicts the life of a young poet, Jaromil, and his mother within Lacanian framework. Married to an unwilling husband, Jaromil's mother fancies regarding him as her own creation and seeing herself as his ethereal mother, but this image contrasts with her actual life. Consequently, the conflict she feels between her ego-ideal and ideal ego pushes her to deal with her psychological tension in Jaromil's existence .On the other side, Jaromil's continuous identifications with the images and signifiers bring him nothing except a nonidentity and unrelenting self-alienation in the context of a socialist system which is supposed to eliminate any sort of alienation. Then, considering Bakhtin's ruminations on parody and its polyphonic nature, we have cast light on Kundera's parodic treatment of the motherhood, poetic, political and historical discourses present in the novel. At last, we have shown how Kundera, through emphasizing the ontological aspects of parody, considers it as the inevitable fate of a human being who has forgotten his authentic "being" and dismissed all his existential possibilities opened up to realization. As we apply this notion to Kundera's relation to his characters, Jaromil and the middle-aged man, we can conclude that these two characters are, in fact, the parody of the two stages of Kundera's own life and that of his generation's.

\section{References}

[1] Abrams, Meyer H., and Geoffrey Galt. Harpham. A Glossary of Literary Terms. Boston, Mass.: Thomson Wadsworth, 2012. Print.

[2] Bachtin, Michail Michajlovic. The Dialogic Imagination: Four Essays. Austin: U of Texas, 1994. Print.

[3] Homer, Sean. Jacques Lacan. London: Routledge, 2005. Print.

[4] Kundera, Milan, and Aaron Asher. Life Is Elsewhere. New York: HarperPerennial, 2000. Print.

[5] Kundera, Milan. The Art of the Novel. New York: Grove, 1988. Print.

[6] Kundera, Milan. The Unbearable Lightness of Being. New York: Harper \& Row, 1984. Print.

[7] Macherey, Pierre, and Geoffrey Wall. A Theory of Literary Production. London: Routledge \& Kegan Paul, 1978. Print.

[8] Marx, Karl. Economic and Philosophic Manuscripts of 1844. Prometheus Books, 1988. Print.

[9] Nelson, Victoria. "Review: The Poet and His Mother." The Threepenny Review No. 24 (1986): 10-11. JSTOR. Web. 20 June 2015.

[10] Ricard, Francois. "Satan's Point of View: Towards A Reading of Life Is Elsewhere." Salmagundi No. 73.Milan Kundera: Fictive Lightness, Fictive Weight (1987): 58-64. JSTOR. Web. 20 June 2015. 
[11] Seaton, James. "Lyric Poetry, the Novel, and Revolution: Milan Kundera's Life Is Elsewhere." N.p., 2007. Web.

[12] Stavrakakis, Yannis. Lacan and the Political. London: Routledge, 1999. Print.

[13] Wilson, Ross. Theodor Adorno. London: Routledge, 2007. Print.

[14] Žižek, Slavoj. The Sublime Object of Ideology. London: Verso, 1989. Print. 